\title{
PEMBERIAN PELLET ECENG GONDOK (Echhornia crassipes) TERHADAP PERTUMBUHAN IKAN NILA MERAH (Oreochoromis sp) DI JARING TANCAP
}

\author{
Cyska Lumenta*) \\ "Fakultas Perikanan Dan IImu Kelautan UNSRAT Manado, 95115
}

ABSTRACT
Lumenta, C. 2006. The Effect of the Movision of Eceng Gondok Pellet (Echhornia crassipes) on the growth of Red Nila Fish (Oreochormis sp) Vared in Setnet. Eugenia 12 (4) : 387-398.

The research of on the growth of red nila fish measuring $10-12 \mathrm{~cm}$ in length and $27-32 \mathrm{~g}$ in weight feed with pellet containy different compocition of eceng gondok leaf powder has been carried out in Tondano lake, Eris village, Eris district, Minahasa Agency. The arm of this rescearch is to find out with compotition $(10 \%, 20 \%, 30 \%)$ of pellet from eceng gondok lef that have different composition $(10 \%, 20 \%$, $30 \%$ ) in pellets give the best relative growth, effisiency value and nutrient convertion value. in comparison with commercial pellets.

The result showed that pellet contaning $10 \%$ eceng gondok powder hed the nigest relative growth (195.4\%0, efficiency value (61.65) and nutrient convertion value (1.6).

Commercial pellet used as control hower is still relatively better compare with all experimental pellets containing defferent competition of eceng gondok in terms of relative growth, effisiency value and nutrient convertion value.

Keywords: Red Nila (Oreochormis Sp), Eceng Gondok Pellets (Echhormia crassipes), Set net (Jaring Tancap)

\section{PENDAHULUAN}

Usaha budidaya perairan telah mengalami kemajuan yang angat pesat hingga akhir abad 20-an. Spesies-spesies ikan baru telah dibudidayakan teknologi baru telah diciptakan dan banyaknya investasi dikeluarkan guna perkembangan usaha budidaya. Sekarang ini usaha budidaya perairan diakui sebagai usaha yang dapat berjalan terus menerus dan dapat memberikan keuntungan (Lovell 1989). Dari semuanya itu diharapkan akan meningkatkan persentase produk-produk perikanan. Salah satu teknologi yang dapat meningkatkan produk-produk perikanan yaitu pemodifikasian pakan bernutrisi lengkap. Pakan merupakan sumber energi untuk pertumbuhan dan untuk menjalankan semua fungsi tubuh, dan pakan merupakan salah satu faktor penting dalam peningkatan produksi ikan.

Protein adalah unsur nutrisi pertama yang harus diperhitungkan dalam membuat formulasi pakan ikan. Namun selama ini kebutuhan protein umumnya masih bergantung pada tepung ikan yang harganya cenderung bertambah mahal dan sebagian besar kebutuhan 